\title{
Some Market Trends of Wood Products Exports in Ghana and Their Implications for Stakeholders: The Case of Furniture and Kiln-Dried Lumber
}

\author{
Peter Kessels Dadzie ${ }^{1, ~ *}$, Kojo Agyapong Afrifah ${ }^{2}$, Paul Benedict Inkum ${ }^{1}$ \\ ${ }^{1}$ Interior Architecture and Furniture Production Department, Faculty of Built and Natural Environment, Kumasi Polytechnic, Kumasi, Ghana \\ ${ }^{2}$ Department of Wood Science and Technology, Faculty of Renewable Natural Resources, Kwame Nkrumah University of Science and \\ Technology, Kumasi, Ghana
}

\section{Email address:}

pkkdadzie@yahoo.com (P. K. Dadzie), peter.kdadzie@kpoly.edu.gh (P. K. Dadzie), kagyapong@gmail.com (K. A. Afrifah)

\section{To cite this article:}

Peter Kessels Dadzie, Kojo Agyapong Afrifah, Paul Benedict Inkum. Some Market Trends of Wood Products Exports in Ghana and Their Implications for Stakeholders: The Case of Furniture and Kiln-Dried Lumber. International Journal of Business and Economics Research. Vol. 4, No. 6, 2015, pp. 307-314. doi: 10.11648/j.ijber.20150406.16

\begin{abstract}
Market trends information like price/value fluctuations aid traders and investors to create profits. This study assessed unit values of garden furniture and lumber among wood species, as well as the destination and product type effect on these values. Reports on wood products export were reviewed to obtain data for analyses. Findings were that values $/ \mathrm{m}^{3}$ of all wood species were higher when used for garden furniture than when used for lumber production for exports. Among the identified wood species for both garden furniture and lumber production for export, Pericopsis elata (afromosia) had the highest value for both furniture $(€ 3,308.844)$ and lumber $(€ 869.00)$ whereas Terminalia ivorensis (emire) had the least furniture value $(€ 1,336.936)$ while Pycnanthus angolensis (otie) had the least lumber value (€263.10). Sweden and Italy respectively offered the highest $(€ 17,891.80)$ and lowest $(€ 1134.30)$ mean garden furniture value, while Sweden and France respectively offered the highest (€557.31) and lowest (€314.97) lumber value. Direction of trade and product type had significant effect $(p<0.01)$ on values of the products and they explained $92.3 \%$ of the variations. Generally, both products registered a decreasing trend in volumes exported over the period but lumber value $/ \mathrm{m}^{3}$ appreciated whereas furniture value $/ \mathrm{m}^{3}$ fell. Conclusions were that the most valued wood species for both lumber and furniture in the export market is afromosia and the best destination for both furniture and kiln-dried lumber export is Sweden. Based on monetary values, it was recommended that garden furniture production for exports should be encouraged than lumber, and furniture export to Sweden could yield higher values $/ \mathrm{m}^{3}$.
\end{abstract}

Keywords: Furniture and Lumber Exports, Wood Products Prices, Ghana's Exports, Market Trends

\section{Introduction}

The forest sector, especially wood products export, is a major contributor to the Ghanaian economy. Reports indicate that the sector, which is dominated by timber industries accounts for about $11 \%$ of the total export earnings of the country [1]. The wood products usually produced in Ghana for the export market include lumber, furniture parts, plywood, glulam etc. In the year 2000, exports of these contributed about $6 \%$ to the Gross Domestic Product (GDP) with the formal sector alone employing labour force of about 100,000 people [1]. Currently, the forest sector provides direct livelihood to about 2million people in total [2]. However, between 1990 and 2005 (a period of 15 years)
Ghana lost about 26\% (1.9million hectares) of its total forest cover due to over exploitation of the forests for timber products, mining and quarrying among others [1]. Deforestation rate in Ghana was thus estimated to be about $2 \%$ per annum and this appears to have continued and have subsequently affected wood products manufacturing and their exports. For instance some wood processing firms have either shut down or operating at less than half of their operational capacities. A manifestation of this appears to be the drastic fall of the forest sector's contribution to GDP from the $6 \%$ in 2000 to $4 \%$ in 2011 [3].

One wood product whose manufacturing and exports have been hard hit by the depletion of the forests is wooden furniture [4-7]. This appears to be due to the fact that they are primarily produced from relatively durable and weather 
resistant wood species such as iroko/odum (Milicia excelsa), mahogany (Khaya spp.), teak (Tectona grandis), utile (Entandrophragma utile), albizia (Albizia ferrugenia) etc. which are also being used for lumber production $[6,8,9]$. It is however, important to note that although garden furniture can be produced with both wood and other metallic materials either alone or in combination, wood has been the most favourite material due to its desirable attributes such as: easiness to work on by using both hand and machine tools; ability to be fastened satisfactorily with adhesive, nails and screws; natural beauty from variations in figure and colour that blends; and resistance to rust and corrosion [10]. Also, because of the labour intensity of the wooden furniture sector, it presents a greater opportunity for developing countries and their firms to participate effectively in the global economy through the offer of employments and generation of relatively higher income [11]. But the same wood species used for these furniture, in addition to other wood species, are being exploited greatly for lumber to the disadvantage of furniture production for exports and local consumption. Such drift or desire to use a material for a particular product in lieu of another one are sometimes determined by some market trends such as appreciation or depreciation of values and how destinations or markets affect the unit price of the product.

In the export market however, furniture parts have much higher value per unit volume than lumber. Trade statistics revealed that the value differences between furniture and air-dried lumber per $\mathrm{m}^{3}$ was $€ 1,362.717$ (432.43\%) and that between furniture and kiln-dried lumber was $€ 1,300.717$ (344.85\%) [12]. Additionally, individual wood species such as Mahogany (Khaya Spp.) had value differences between its kiln-dried lumber and its furniture to be about $200.07 \%$, while Odum (Milicia excelsa) recorded a value increase of $178.10 \%$ [13].

Besides the foregoing, some report has also proven through some varied scenarios that incurring extra costs to convert kiln-dried lumber to furniture in Ghana for exports is profitable [14]. It is again important to note that though in every business endeavour, profit (economic feasibility) is the third, final and the most important level in business feasibility studies and which indicates the economic sense of a business proponent which has been found to be workable when actually implemented [15]. Therefore, profits appear to be one of the major prime motives of almost every business, and furniture and lumber production for export as businesses cannot be exceptions. However, the unit value and quantities/volumes of a product sold also play very important role in profit making [16]. Meanwhile, it appears that in the wood industry, direction of trade (i.e. destination) also appears to significantly influence the unit value of both furniture and lumber products exports [17] which could consequently affect the potential profits of firms engaging in the manufacturing and exports of any of the two products. However, studies appear limited or unavailable on market trends such as unit price fluctuations over a considerable period of time especially in relation to lumber and furniture produced in Ghana for the export markets and whether or not significant differences exist between these values across importing countries/direction of trade and among wood species. Studies on such market trends are necessary since they provide producers and traders with vital information that could lead to higher profits as they help the exploration of products and trading partners or destination that could yield higher returns or income towards higher profits [18].

This study therefore assessed the trend of average value $/ \mathrm{m}^{3}$ of kiln-dried (K.D) lumber and garden furniture across wood species and importing countries (direction of trade), the influence of direction of trade and product type on the value $/ \mathrm{m}^{3}$ of lumber and garden furniture and the trends of unit price and volume fluctuations of lumber and furniture exported over a period and discuss their implications for stakeholders such as producers, timber trade regulatory institutions and the government in general. These are expected to aid in providing some direction to current and prospective producers and stakeholders in the timber products industries, especially in ascertaining which direction of trade could be more profitable for each of the products, among other things.

\section{Materials and Methods}

\subsection{Data Collection}

\subsubsection{Average Value/m ${ }^{3}$ (Free-on-Board FOB) of Kiln- Dried Lumber and Garden Furniture among Wood Species}

The average FOB values $/ \mathrm{m}^{3}$ of each specific wood species used for both garden furniture and kiln-dried lumber production from 2001 to 2008 were extracted from TIDD's export reports on wood products [4-7, 19-22]. These average values were obtained by dividing each product's cumulative values by their respective cumulative volumes exported in each year. The mean values $/ \mathrm{m}^{3}$ of each wood species for either lumber or furniture for the 8 years were used as the average value of each species for the period. However, those species that had 4 or more years (i.e. $\geq 50 \%$ of the study period) appearances in both the furniture and lumber export markets were used for the statistical analysis.

\subsubsection{Average Value/M ${ }^{3}$ of Kiln-Dried Lumber and Garden Furniture Among Importing Countries}

The average FOB values $/ \mathrm{m}^{3}$ of garden furniture in general (i.e. without considering specific wood species) imported by each country were first extracted from TIDD's export reports on wood products for the period of study (i.e. 8 years). This was done by dividing their cumulative values by their respective cumulative volumes for each year from 2001 to 2008. The mean for the 8 years was used as the average purchased value $/ \mathrm{m}^{3}$ offered for the product in that country. After identifying all the countries that import furniture products from Ghana, their kiln-dried lumber imports were also traced and subsequently their average values $/ \mathrm{m}^{3}$ for each year were determined as was done in the case of garden 
furniture. All these estimates were done without considering any specific species but the products in general (i.e. kilndried lumber and garden furniture). However, those destinations (importing countries) that had 4 or more years (i.e. $\geq 50 \%$ of the study period) trading in both furniture and lumber from Ghana were used for the statistical analysis.

\subsection{Data Analyses}

Data obtained on volumes and values of garden furniture exports across species, years and importing countries were analysed using Microsoft Excel 2003 and 2007 to determine their trends. SPSS 17.0 was also used to perform independent sample T-test and ANOVA tests to determine significant differences and the influence of direction of trade and product type on the variations in values $/ \mathrm{m}^{3}$ of kiln-dried lumber and garden furniture among species and importing countries.

\section{Results and Discussions}

\subsection{Average Value/M ${ }^{3}$ for Kiln-Dried Lumber and Garden Furniture of Specific Wood Species}

Table 1 shows the statistical analysis of the mean values $/ \mathrm{m}^{3}$ of kiln-dried lumber and garden furniture $(€)$ for 15 species that had equal to or greater than $50 \%$ appearance in both lumber and garden furniture markets out of the 8 year period of this study (i.e. species that had $\geq 4$ years of the 8 years of this study).

Table 1. Statistical analysis of mean values $/ \mathrm{m}^{3}$ of Kiln-dried Lumber and Garden Furniture among Wood Species.

\begin{tabular}{|c|c|c|c|c|}
\hline \multirow{2}{*}{ Wood Species } & \multicolumn{2}{|c|}{ Value of products $/ \mathbf{m}^{3}(€)$} & \multirow{2}{*}{ T- Value } & \multirow{2}{*}{ P-Value } \\
\hline & Kiln-Dried Lumber (SD) & Garden Furniture (SD) & & \\
\hline Milicia excelsa (odum) & $667.40(39.46)^{\mathrm{abcdefgh}}$ & $2469.00(307.47)^{1,2,3,30,36,43,50}$ & -16.438 & .000 \\
\hline Turreanthus africanus (avodire) & $397.76(104.24)^{\mathrm{a} \mathrm{i}}$ & $1657.70(667.61)^{1,4,10,13,20,29}$ & -5.293 & .000 \\
\hline Afzelia africana (Papao/apa) & $588.51(104.24)^{\mathrm{ijk}}$ & $1281.11(143.20)^{2,4,5,7,9,11,19,28,29}$ & -12.958 & .000 \\
\hline Albizia ferrugenia (albizia) & $396.27(82.84)^{\mathrm{clx}}$ & $1546.40(1154.13)^{3,6,8,10,18,27,38}$ & -2.826 & .014 \\
\hline Daniellia ogea (Ogea) & $528.89(268.24)^{\mathrm{jmnop}}$ & $2413.90(890.66)^{5,6,10,26,35,42,49}$ & -3.474 & .018 \\
\hline Khaya spp. (mahogany) & $633.01(32.48)^{q}$ & $1815.00(218.41)^{7,8,17,25,34}$ & -15.141 & .000 \\
\hline Mixed redwood & $317.65(83.86)^{\mathrm{dr}}$ & $1774.90(483.40)^{9,12,16,24}$ & -8.401 & .000 \\
\hline Nesogordonia papaverifera (danta) & $409.12(150.33)^{\mathrm{x}}$ & $2261.30(1491.43)^{11,12,13,14,23,33,41}$ & -3.697 & .004 \\
\hline Pericopsis elata (afromosia) & $869.00(114.56)^{\text {abcdefgh } 1 j k 1 m n \text { opqrstuvwx }}$ & $\begin{array}{l}3308.80(716.48)^{1,2,3,4,5,6,7,8,9,10,11,12,} \\
13,14,15,22,32,37,40,46\end{array}$ & -4.536 & .006 \\
\hline Tectona gradis (teak) & $545.44(226.46)^{\mathrm{ijk} \text { lrstuv }}$ & $2785.20(704.27)^{15,16,17,18,19,20,21,31,40,48}$ & -8.544 & .000 \\
\hline Terminalia ivorensis (emire) & $409.66(34.57)^{\mathrm{em} \mathrm{q} \mathrm{sw}}$ & 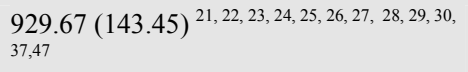 & -10.00 & .000 \\
\hline Piptadeniastrum africanum (dahoma) & $315.98(15.78)^{\mathrm{fnt}}$ & $1190.00(382.74)^{31,32,33,34,35,36,37}$ & -6.543 & .000 \\
\hline Chrysophyllum spp. (Akasaa) & $499.95(65.28)^{\text {gou }}$ & $1176.20(129.8)^{40,41,42,43,44}$ & -12.668 & .000 \\
\hline Guibourtia ehie (hyedua) & $643.43(203.58)^{\mathrm{w}}$ & $2315.30(329.68)^{37,38,39,44,45}$ & -10.556 & .000 \\
\hline Pycnanthus angolensis (otie) & $263.10(101.30)^{\mathrm{hpv}}$ & $1521.70(95.44)^{45,46,47,48,49,50}$ & -20.640 & .000 \\
\hline
\end{tabular}

Mean values with the same letters or numerals indicate significant difference at $95 \%$ confidence level. Alphabets indicate differences in lumber values and numerals indicate differences in furniture values.

Therefore, these 15 species (Table 1) could be classified as the most desired ones for both furniture and lumber production in Ghana for export and as such, they are highly competitive for both two products (i.e. lumber and furniture) and therefore such wood species are highly affected by the depletion of Ghana's forest. It is however important to note that these 15 species come from a total of 26 already identified wood species used in Ghana for the production of furniture parts for the export market [23]. Among these most desired wood species Pericopsis elata (afromosia) had the highest value for furniture $(€ 3,308.80)$ and lumber (€869.00). This resulted in a significant $(\mathrm{T}=3.697, \mathrm{p}=0.004)$ value difference of $€ 2439.844$ equivalent to $280.76 \%$ higher than the value of the species' lumber. However, Terminalia ivorensis (emire) had the least furniture value of $€ 929.67$ while Pycnanthus angolensis (otie) had the least kiln-dried lumber value of $€ 263.10$. The values $/ \mathrm{m}^{3}$ of lumber from the species appear to be within the ranges reported in literature as; afromosia (\$855), dahoma (\$315 - \$390), emere (\$350 $\$ 400)$, mahogany (\$556 - \$665), and odum (\$630 - \$690) [24]. As was expected, FOB values of furniture were significantly $(\mathrm{P}<0.01)$ higher than those of kiln-dried lumber for all same wood species in the export markets. Again, the value of kiln-dried lumber produced from afromosia wood happened to be significantly $(p<0.05)$ higher than the values of lumber produced from almost all the other species. Similar trend was also observed that the value of furniture produced from afromosia had significantly $(\mathrm{p}<0.05)$ higher value than furniture produced from almost all the other species. These give indication that afromosia wood has significantly higher value for its lumber and garden furniture than all the other species. And this is confirmed in [24]. The 
implication is that industries and other stakeholders such as the Timber Industry Development Division - TIDD and the Government should consider afromosia wood plantations for higher export returns or earnings in their medium to long term efforts at replenishing Ghana's lost forest through afforestation and reforestation.

From the foregoing statistics (Table 1), wood species or type of product appear to have some influence on the value $/ \mathrm{m}^{3}$ of each of the two products.

Table 2. Two-Way ANOVA of the effect of wood species and product type on the values $(\epsilon)$ of Kiln-dried Lumber and Garden Furniture in the export markets.

\begin{tabular}{llllll}
\hline Source & Type III Sum of Squares & df & Mean Square & F & Sig. \\
\hline Corrected Model & $1.665 \mathrm{E}^{\mathrm{a}}$ & 31 & 5370144.882 & 29.705 & .000 \\
Intercept & $2.650 \mathrm{E} 8$ & 1 & $2.650 \mathrm{E} 8$ & $1.466 \mathrm{E} 3$ & .000 \\
Wood_Species & $2.725 \mathrm{E} 7$ & 15 & 1816426.165 & 10.047 & .000 \\
Product_Type & $8.944 \mathrm{E} 7$ & 1 & $8.944 \mathrm{E} 7$ & 494.742 & .000 \\
Wood_Species * Product_Type & $1.531 \mathrm{E} 7$ & 15 & 1020555.470 & 5.645 & .000 \\
Error & $4.773 \mathrm{E} 7$ & 264 & 180784.922 & & \\
Total & $4.617 \mathrm{E} 8$ & 296 & & & \\
Corrected Total & $2.142 \mathrm{E} 8$ & 295 & & & \\
\hline
\end{tabular}

a. R Squared $=.777$ (Adjusted R Squared $=.751)$

Hence, further statistical analysis (Two-Way ANOVATable 2) was conducted and it indicated that wood species $(\mathrm{F}=10.047, \mathrm{P}=.000)$, product type $(\mathrm{F}=494.742, \mathrm{P}=.000)$ and the interaction of wood species and product type $(\mathrm{F}=5.645, \mathrm{P}=.000)$ have significant effect on the values of the products studied. The influences of wood species and product type on prices or values per cubic meter of wood products appear consistent with reports in literature [24]. Additionally, these variables explained about $75 \%$ (indicated beneath Table 2) of the variations in the export values of kilndried lumber and garden furniture.

\subsection{Average Value/m ${ }^{3}$ (€) of Kiln-Dried Lumber and Garden Furniture among Importing Countries}

In all, out of a total of 14 countries that import both furniture and lumber from Ghana [23], 9 of them were found to have had at least 4 years trading in furniture and lumber from Ghana representing $\geq 50 \%$ of the 8 years period of this study. Thus these 9 countries were used for the statistical analysis (Table 3). However, among these countries, Sweden and Italy respectively offered the highest $(€ 17,891.80)$ and lowest $(€ 1134.30)$ mean furniture values $/ \mathrm{m}^{3}$, whereas Sweden and France respectively offered the highest $(€ 557.31)$ and lowest $(€ 314.97)$ kiln-dried lumber values $/ \mathrm{m}^{3}$. The findings in Table 3 appear to disagree with the report by [24] that European countries' interest in West African wood products remains very subdued since many of the markets for Ghanaian lumber and wooden furniture are the European nations (Table 3 ).

Table 3. Statistical analysis of mean values of $1 \mathrm{~m}^{3}$ Kiln-dried Lumber and Garden Furniture among importing countries.

\begin{tabular}{|c|c|c|c|c|}
\hline \multirow{2}{*}{ Importing Country or Direction of Trade } & \multicolumn{2}{|l|}{ Products Value/m $(€)$} & \multirow{2}{*}{ T- Value } & \multirow{2}{*}{ P- Value } \\
\hline & Kiln-Dried Lumber (SD) & Garden Furniture (SD) & & \\
\hline U. K & $381.89(31.79)^{h}$ & $2167.60(328.21)^{1}$ & -21.016 & .000 \\
\hline Holland & $371.60(50.62)^{\mathrm{i}}$ & $2986.50(1082.64)^{2,9,10,11,12,13,14}$ & -7.539 & .000 \\
\hline Ireland & $491.96(183.97)^{\mathrm{abcd}}$ & $3729.60(2094.18)^{1,2,3,4,5,6,7,8}$ & -4.377 & .001 \\
\hline Italy & $322.97(29.51)^{\mathrm{a} \mathrm{e} \mathrm{j} \mathrm{k}}$ & $1134.30(196.82)^{3,14}$ & -11.762 & .000 \\
\hline Germany & $316.11(26.91)^{\mathrm{bfk}}$ & $2469.00(1149.29)^{4,9}$ & -5.581 & .000 \\
\hline Spain & $373.73(82.98)^{g}$ & $1163.90(385.90)^{5,10}$ & -5.693 & .000 \\
\hline Sweden & $557.31(85.77)^{\text {efghijklm }}$ & $17892.00(1260.31)^{6,11}$ & -272.254 & .000 \\
\hline Belgium & $346.15(31.87)^{\mathrm{cl}}$ & $1584.00(405.53)^{7,12}$ & -9.463 & .000 \\
\hline France & $314.97(23.45)^{\mathrm{md}}$ & $1867.10(1998.24)^{8,13}$ & -2.315 & .043 \\
\hline
\end{tabular}

Mean values with the same letters or numerals indicate significant difference at $95 \%$ confidence level. Alphabets indicate differences in lumber values and Arabic numerals indicate differences in furniture values.

These findings (Table 3) obviously mean that different countries apparently offer different prices $/ \mathrm{m}^{3}$ for either lumber or furniture and the country that offers either a higher or lower value for lumber does not necessarily offer same for furniture. And this is also consistent with report by [24]. Some implications of these findings are that producers and exporters should not take it for granted that destinations or importing countries that offer higher prices for lumber may 
not necessarily do same for furniture and therefore offers from countries should be treated on their own merits.

It is interesting to know that, within the 8 years period covered by this study, U.S.A was not among the countries that imported furniture from Ghana up to $50 \%$ of the period of this study, implying that furniture exports to U.S.A appear irregular and possibly not to any larger quantity. This finding on U.S.A appears to contradict that of [25] that U.S.A, India and Italy are among the 10 major importers of Ghana's wood products. But this contradiction could be due to the focus of this study which was on only kiln-dried lumber and garden furniture and not on all wood products produced in Ghana for exports. These results (Table 3) suggest that direction of trade (destinations) and the product type (either furniture or lumber) appeared to have some influence on the values of the products. However, the value $/ \mathrm{m}^{3}$ of furniture parts $(€ 17$, 89.00) in Sweden appeared to be exceptionally higher than all the other trading partners since no country offered even up to $€ 4000.00 / \mathrm{m}^{3}$ for furniture in any of the years under review. Therefore, such extraordinarily high value could be attributed to some other factors other than destination or product type. However, a Two-Way ANOVA was conducted (Table 4) to ascertain the extent to which direction of trade or product type affect the value $/ \mathrm{m}^{3}$ of lumber or furniture.

Table 4. Two-Way ANOVA of the influence of direction of Trade (Importing Country) and Product type on the variations in Values $/ \mathrm{m}^{3}$ of lumber and furniture.

\begin{tabular}{llllll}
\hline Source & Type III Sum of Squares & df & Mean Square & F & Sig. \\
\hline Corrected Model & $6.933 \mathrm{E}^{\mathrm{a}}$ & 26 & $2.666 \mathrm{E} 7$ & 70.147 & .000 \\
Intercept & $2.046 \mathrm{E} 8$ & 1 & $2.046 \mathrm{E} 8$ & 538.218 & .000 \\
Direction_of_Trade & $4.077 \mathrm{E} 8$ & 13 & $3.136 \mathrm{E} 7$ & 82.500 & .000 \\
Product Type & $1.448 \mathrm{E} 8$ & 1 & $1.448 \mathrm{E} 8$ & 380.959 & .000 \\
Direction_of_Trade * Product & $3.866 \mathrm{E} 8$ & 12 & $3.222 \mathrm{E} 7$ & 84.758 & .000 \\
Error & $4.676 \mathrm{E} 7$ & 123 & 380122.556 & & \\
Total & $9.370 \mathrm{E} 8$ & 150 & & & \\
Corrected Total & $7.400 \mathrm{E} 8$ & 149 & & & \\
\hline
\end{tabular}

a. R Squared $=.937$ (Adjusted R Squared $=.923)$

Results indicated that direction of trade or importing country $(F=82.500 ; p=0.000)$, product type (furniture or lumber $)(F=380.959 ; p=0.000)$ and the interactions between the two variables $(F=84.758 ; p=0.000)$ all had significant effect on the value $/ \mathrm{m}^{3}$ of the two products. These findings however, agree with the report by [24] that destinations and product type have effect on the prices or values per cubic meter of wood products. Moreover, direction of trade and product type was found to have explained about $92.3 \%$ (as indicated by the adjusted $\mathrm{R}^{2}$ value beneath Table 4) of the variations in the prices of the two products among the importing countries. Some implications of these findings are that the value $/ \mathrm{m}^{3}$ of both furniture and lumber in the export markets is highly influenced by the importing country and therefore producers, exporters and other stakeholders in timber products trading should not relent in their efforts at securing contracts from countries that will offer higher values since these values $/ \mathrm{m}^{3}$ will affect the profit margins of the producers and exporters.

\subsection{Trends of Average Volume $\left(M^{3}\right)$ and Value/M $M^{3}(\epsilon)$ of Kiln-Dried Lumber and Garden Furniture Exports from Ghana over the Period}

Figures 1 and 2 respectively show the mean volumes $\left(\mathrm{m}^{3}\right)$ and values $(€)$ of kiln-dried lumber and garden furniture (G.F) exports from Ghana over the period of this study.

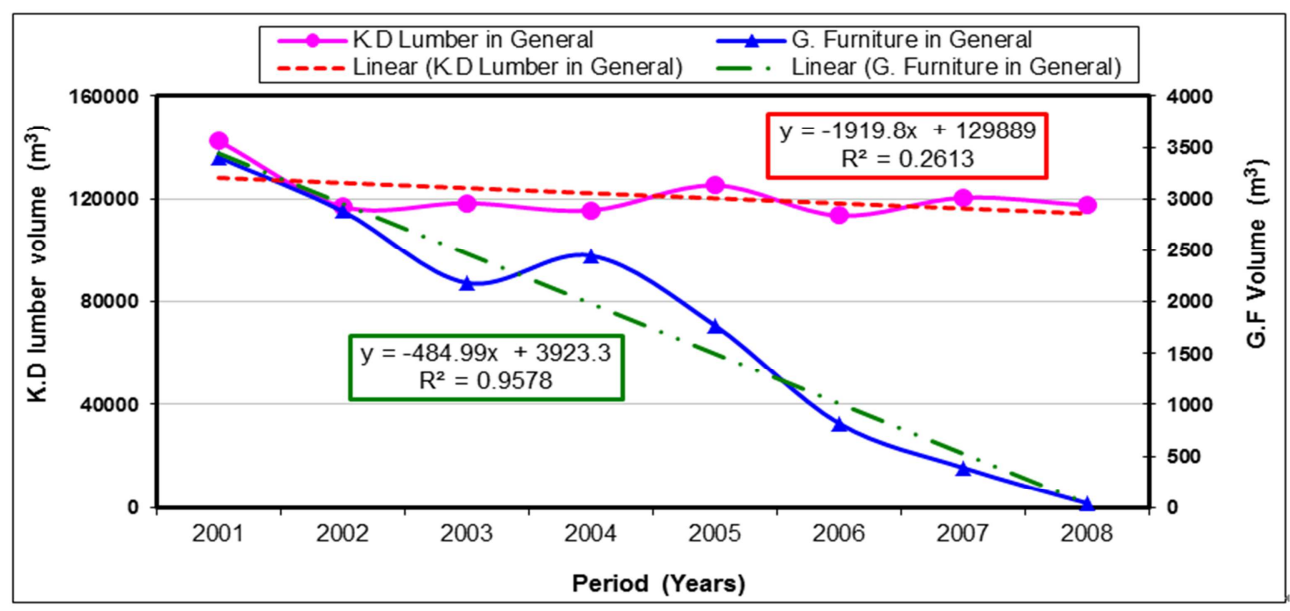

Figure 1. Average volume $\left(\mathrm{m}^{3}\right)$ of kiln-dried (K.D) lumber and garden furniture (G.F) exports from Ghana from 2001-2008. Source: TIDD export reports 2001 to 2008 . 
From figure 1, the quantity of both lumber and furniture exported from Ghana has generally declined from 2001 to 2008. This appears consistent with the report of [24] that market growth for kiln-dried lumber from Ghana has exhibited a slow pace or declining trend. However, the degree of decline appears higher for furniture than for lumber as indicated by the linear regression lines. Moreover, it also appears clear that furniture exports from Ghana after 2008 approached zero but lumber exports was still around $120,000 \mathrm{~m}^{3}$ per annum though it also appeared declining slowly. This appears to support report that firms in Africa, including Ghana appear to be exporters of raw or low valued products compared to valueadded products whose prices are high [26, 27].

From figure 2, whereas the values $/ \mathrm{m}^{3}(€)$ of kiln-dried lumber generally appreciated by about 6.3 times per annum over the period of this study, those of garden furniture depreciated by as high as 67.24 times per annum as indicated by the coefficients of ' $X$ ' in the regression equations (Figure 2 ). This could be one reason accounting for the seeming disinterest among Ghanaian wood products manufacturers to either continue engaging in or start to invest in furniture production for exports. But, despite the decline in value $/ \mathrm{m}^{3}$ of garden furniture over the years, it is reported that its production in Ghana for exports is generally profitable and various scenarios have proven that garden furniture production for export could result in additional net profits that range from the lowest of $12.4 \%$ to as high as $62.7 \%$ per cubic metre over and above the FOB value of the quantities of kiln-dried lumber used [13, 27, 28].

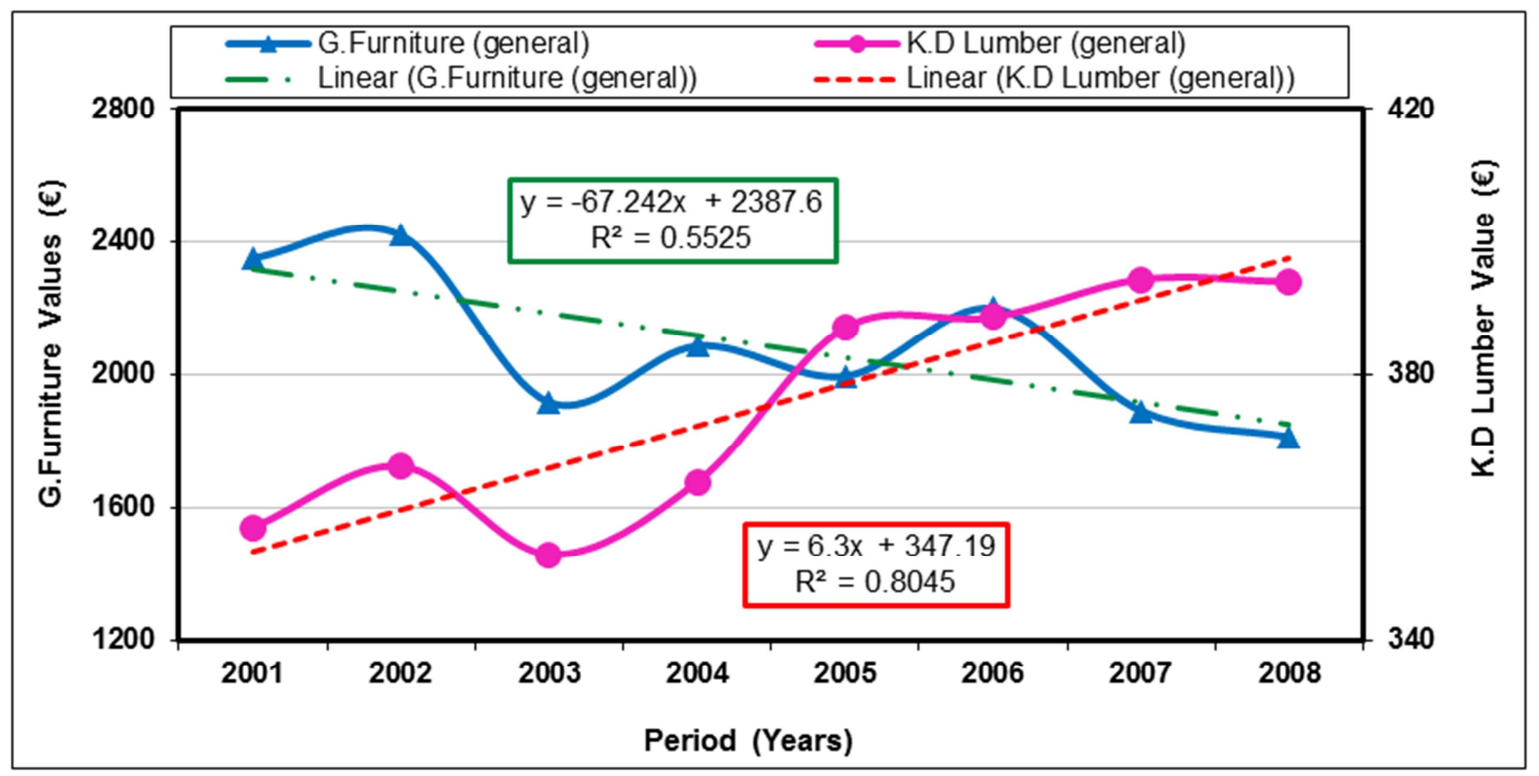

Figure 2. Average value $\mathrm{m}^{3}(\epsilon)$ of kiln-dried (K.D) lumber and garden furniture (G.F) exports from Ghana from 2001 to 2008. Source: TIDD export reports 2001 to 2008

Though from the foregoing results (Figures 1 and 2), there are appreciable downwards trend in terms of volume and value $/ \mathrm{m}^{3}$ of garden furniture exported, the results in Tables 1 and 3 give hope and therefore it is imperative that industry and government, as well as other stakeholders in the wood products industry, fashion out strategies that could work towards increasing furniture production in Ghana for exports so as to rake in more foreign exchange. For instance, industry could begin to invest in equipment and machinery that can enable them to further process majority of lumber to furniture before exports. In this wise, the government and other timber trade regulatory bodies, on the other hand, could also provide some incentives such as tax exemptions, duty-free regimes on the equipment, among others. Such interventions could have the potential of enticing existing and potential entrepreneurs or industrialists in the wood processing sector to venture into furniture and other tertiary wood products manufacturing which could in turn lead to more employment and subsequently result in more income tax revenues to government, improvement in the economic lives of people and the general economy of the country. All of these could possibly reduce crime, other social vices and negative livestyles of the citizenry.

\section{Conclusions and Recommendations}

Based on the results, the following conclusions were drawn;

1. Furniture and lumber produced from Pericopsis elata (afromosia) wood are the most valued ones in the export markets whereas Terminalia ivorensis (emire) and Pycnanthus angolensis (otie) are the least valued species for furniture and lumber respectively. Wood species had significant effect on the values $/ \mathrm{m}^{3}$ of lumber and furniture.

2. In terms of export value $/ \mathrm{m}^{3}$, among the trading partners or destinations, Sweden and Italy were respectively the best and worst destinations for Ghanaian furniture 
whereas Sweden and France were also respectively the best and worst destinations for lumber from Ghana. Also, direction of trade (destination) and product type (furniture or lumber) had significant effect on the unit prices or values of both lumber and garden furniture.

3. Trends of unit value and volume of lumber and furniture exports indicated that generally, the export volumes of both furniture and lumber have fallen over the period. However, unlike furniture, the price or value $/ \mathrm{m}^{3}$ of kiln-dried lumber have experienced some steady appreciation.

4. It was recommended that garden furniture could result in higher incomes than lumber exports and much effort should be made to encourage its production and exports than lumber.

\section{References}

[1] Food and Agricultural Organization -FAO (2001). State of the World's Forests 2001. Food And Agriculture Organization of the United Nations, Rome.

[2] The Ghanaian Times (2015). Ghanaian Times Newspaper of January 23, www.ghanaiantimes.com.gh/. (Accessed, $3^{\text {rd }}$ February 2015).

[3] Ministry of Lands and Natural Resources-MLNR. (2012). Ghana-Forest Investment Program (FIP) Plan. Draft-March 2012: 5-66.

[4] TIDD.-Timber Industries Development Division (2001). Exporters performance/moving species/direction of tradelumber $(\mathrm{KD})$ and furniture parts; wood products export report, December, Data Processing Section, Takoradi. Ghana. 33pp.

[5] TIDD.- Timber Industries Development Division (2002). Exporters performance/moving Species/direction of tradelumber (KD) and furniture parts; wood products export report, December, data processing section, Takoradi. Ghana. 36pp.

[6] TIDD.-Timber Industries Development Division (2003). Exporters performance/moving species/direction of tradelumber (KD) and furniture parts; wood products export report, December, data processing section, Takoradi. Ghana. 36pp.

[7] TIDD.-Timber Industries Development Division (2004). Exporters performance/moving species/direction of tradelumber (KD) and furniture parts; wood products export report, December, data processing section, Takoradi. Ghana. 42pp.

[8] Alexander Rose Ltd. (2005). Fine quality traditional garden furniture, Alexander Rose Ltd, West Sussex. U.K. 25pp.

[9] Plow, and Heart Inc. (2006). Furniture Buying Guide. www.plowhearth.com/ Outlet Store. Asp. (Accessed April, 2006).

[10] Ratnasingam, J. (1998). The South-East Asian furniture industry siege, Southern African Wood and Timber Times 24 (1) $68-72$.

[11] Kaplinsky, R., Memedovic, O., Morris, M. (2003). The Global wood Furniture value chain; what prospects for upgrading by developing countries - The case of South Africa, United Nations Industrial Development Organization, Vienna International Centre, Vienna, Austria. Pp. 36.
[12] Dadzie, P. K. (2015). Furniture and Lumber Exports from Ghana: A Comparative Study of Some Market Trends, a Conference paper presented at the $58^{\text {th }}$ International Convention of the Society of Wood Science and Technology (SWST), Grand Teton National Park, Jackson, Wyoming, U.S.A $7^{\text {th }}-12^{\text {th }}$ June, 2015.

[13] TIDD. - Timber Industries Development Division (2005a). The first 30 out of 126 exporters of all wood products, jan-feb 2005. wood products' export report for February 2005, data processing section of TIDD, Takoradi, Ghana. $32 \mathrm{pp}$.

[14] Dadzie, P. K., Frimpong-Mensah, K., Amoah, M. and Boampong, E. (2015). Scenario Analysis of Profits in Further Processing Lumber to Furniture in Ghana for Export: A Case Study of a Local Firm, International Journal of Business and Economic Research, 4(2): 55-66.

[15] Amanor-Boadu, V. (n.d). Assessing the Feasibility of Business Propostions. Retrieved from www.agmananger.info/agrbus/busdev/feasibility/feasibilityRe port.pdf. (Accessed, 16th August, 2015).

[16] Cooney, T. M. (1987). Computer Programmes help Loggers to Increase Revenues, Journal of Forestry. pp 13-15.

[17] Bandara, W. A. R. T. W. and Vlosky, R. P. (2012). Analysis of the U. S. Wood Products Import Sector: Prospects for the Tropical Wood Products Exporters, Journal of Tropical Forestry and Environment, 2 (2) 49-52.

[18] Mitchell, C. (2015). 4 Factors that shape market trends. Retrieved from www.Investopedia.com (Accessed, 20 ${ }^{\text {th }}$ October, 2015).

[19] TIDD-Timber Industries Development Division (2005b). Exporters performance/moving species/direction of tradelumber $(\mathrm{KD})$, flooring and furniture parts. report on export of wood products for December 2005, data processing section of TIDD, Takoradi, Ghana. 54 pp.

[20] TIDD-Timber Industries Development Division (2006). Exporters performance/moving species/direction of tradelumber (KD) and furniture parts; wood products export report, December, data processing section, Takoradi. Ghana. $36 \mathrm{pp}$.

[21] TIDD-Timber Industries Development Division (2007). Exporters performance/moving Species/direction of tradelumber (KD) and furniture parts; wood products export report, December, data processing section, Takoradi. Ghana. 31pp.

[22] TIDD- Timber Industries Development Division (2008). Exporters performance/moving species/direction of tradelumber (KD) and furniture parts; wood products export report, December, data processing section, Takoradi. Ghana. 41 pp.

[23] Dadzie, P. K., Amoah, M., Tekpetey, S. L. (2014): Preliminary assessment of wealth creation in wood products' business in Ghana: The perspective of lumber and furniture production and implications for entrepreneurship, International Journal of Business and Economic Research, 3(6): 243-249.

[24] ITTO -International Timber Trade Organization (2010). Tropical Timber Market Report, 15 (7), 1-19.

[25] Doomson, O., Vlosky, R. P. (2007). A strategic overview of the forest sector in Ghana, Louisiana Forest Products Development Centre working paper \#81, School of Renewable Natural Resources, Lousiana State University of Agricultural Centre, Baton Rouge. U.S.A. 17pp. 
[26] Capito, E. (1993). Situation of African Forestry Policy. ATO, Information Bulletin No. 2 (1994) SGIT Impremerie de Louis, Gabon. pp.10-12.

[27] AFORNET- African Forest Research Network (2000). Wood Based Industries in Sub-Saharan Africa. www.afornet.org, (Accessed, 16 ${ }^{\text {th }}$ August, 2005).
[28] Dadzie, P. K., Frimpong-Mensah, K. (2011). Value addition to wood resources, the case of garden furniture production and export in Ghana; A case study of a local firm, conference paper presented at the $65^{\text {th }}$ international convention of the Forest Products Society, 19th -21st June 2011, Portland, Oregon. U.S.A. 